\title{
Twice Weekly
}

National Cancer Institute

\section{Source}

National Cancer Institute. Twice Weekly. NCI Thesaurus. Code C64497.

Two times per week. 